\title{
Analysis of Community Perceptions of Social Welfare in Batam City After the 2019 Presidential Election
}

\author{
Yudhitia $^{1}$, Dhani Akbar ${ }^{2}$, Mahadiansar $^{*}$ \\ ${ }^{1}$ Regional Representative Council of the Riau Islands Province, Indonesia \\ ${ }^{2}$ Internasional Relation Sciences, Faculty of Social and Political Sciences, Raja Ali \\ Haji Maritime University, Riau Islands. Indonesia \\ ${ }^{3}$ Public Administration, Faculty of Administrative Sciences, Brawijaya University \\ Malang, Indonesia \\ *Corespending author:1yudithi_a@yahoo.com; ${ }^{2}$ rittersarmy@gmail.com; \\ 3*mahadiansar@student.ub.ac.id
}

\begin{abstract}
Social welfare has been a part of the impact of population growth centers in overcoming poverty levels in Indonesia. Community perception is needed as an effort to revive that social welfare is an inseparable part of daily life and is very important in the effort of the government's role in overcoming the disparities that occur given the unstable economic growth in each year. This research was conducted with the aim to analyze people's perceptions of social welfare that occurs in the Batam city community. The method used is survey research in each district in Batam City with descriptive methods that are perceptual sharing of ten categories of assessment, data collected through the distribution of interview questionnaires, observations and supported by secondary data. The focus of this research is on community perceptions of social welfare in Batam City with descriptive qualitative data analysis used to approach that used an average score of interpretation of 0.6 with a scale of $1-4$. The results of the analysis show that the indicator of the perception of the people of Batam on social welfare does not have a big impact by the people who only agree to perceive that; (P7) Government programs on social welfare that are right on target felt by the community and (P8) Empowerment of local wisdom / MSMEs that are right on target felt by the community.
\end{abstract}

Keywords: Border; Perception; Social Welfare; Society 


\section{Introduction}

Perception is defined as an act of compiling, predicting and translating information that is owned in order to provide an overview of the object of events and understanding around the environment ${ }^{1}$. Perseption is a part of the learning process, memory and hopes to be expressed ${ }^{2}$. Meanwhile Robbins, Odendaal, and Roodt, concluded that perception can be described as related to the environment as a process in which individuals organize ${ }^{3}$. Then Kinicki and Kreitner interpreted perception as an attempt to translate and understand the impression that will occur $^{4}$. then Kotler explained the perception that a person can choose to organize and interpret information into a meaningful meaning for their life ${ }^{5}$. Kelley 1971 in the theory of perception there will be a relationship of effort made when several individuals observe behavior to determine whether the action is caused by internal factors or external factors ${ }^{6}$

Perception is an individual view that makes it a strong driving force for an action. Managing information and relating to past experiences allows a person to create an overview where to see what will happen through socio-cultural influences where each individual is equipped with personal life experiences that affect perceptions ${ }^{7}$. Batam, which is one of the cities that is quite developed in the Riau Islands Province, has met its heyday during the Batam Authority era. This is shown by the large number of newcomers trying their luck in a city that was once predicted to become The Second Singapore. As a region close to the border with a developed country, the growth expectations of this city are quite high, especially with the special Free Trade Zone (FTZ) policy.

For a city in the border area, Batam has quite good Human Resources (HR), where there are $67.95 \%$ of the productive age, of which $96.54 \%$ live in urban areas. Batam, which was once thrived by international industries, was able to absorb a fantastic workforce, however, the impact of the global economic recession was inevitable. In the reign of President Joko Widodo 2014-2019, there was

\footnotetext{
Schacter, and Daniel. 2011. Psychology + Psychinvestigator. New York: Worth Publisher.

Gregory, Richard L. 1987. Perceptions. Psychology. New York: Routledge

3 Robbins, Stephen P., Aletta. Odendaal, and G. Roodt. 2003. Organizational Behavior : Global and Southern African Perspectives. Pearson Education South Africa.

4 Kinicki, Angelo., and Robert. Kreitner. 2005. Organizational Behavior : Concepts, Skills \& Best Practices. Fourth.

5 Kotler, Philip. 2000. Marketing Management. Prentice Hall of India.

6 Kelley, Harold H. 1971. Attribution in Social Interaction. Morristwon: General Learning Press.

7 McDonald, Susan M. 2012. "Perception : A concept analysis." Internasional Journal of Nursing Knowledge 23 (1): 1-8.
} 
an extraordinary political turmoil. Indonesian politics, according to Power 2018 there was a decline in the quality of democratic institutions in Indonesia, which of course has implications for investment and economic growth ${ }^{8}$. The indications of a conservatism and the over repressive attitude towards the opposition, causing a little turbulence on social stability in Indonesia, which was felt by the community in border areas. Therefore, after the 2019 presidential election, it is interesting to trace how the community in the border areas are established, respond to and the leadership expected in the future.

The focus of this paper discusses the perceptions of Batam city community, the Riau Islands province, Batam city was chosen as the object of this study because there are several important reasons. first, the Batam city population has grown very significantly compared to the other regencies and cities in the Riau Islands, Batam also the centere of economic development in the Riau Islands province. this is because the denser the population will have a major impact on social welfare. Second Batam is famous by industrial sectors which have a big impact on social welfare because many foreign industrial sectors have entered the Batam city areas. Therefore, the researchers conducted an analytical study oriented towards the perception of social welfare in Batam City. As it is known, the role, involvement and participation of the community in this perception analysis is very important to measure the extent of the welfare of the community in recent years.

Table 1. Total Population of Batam City

\begin{tabular}{ccc}
\multicolumn{3}{c}{$(2014-2018)$} \\
\cline { 2 - 3 } No & Year & Population \\
\hline 1 & 2014 & 1.030 .428 \\
2 & 2015 & 1.188 .985 \\
3 & 2016 & 1.236 .399 \\
4 & 2017 & 1.283 .196 \\
5 & 2018 & 1.329 .773 \\
\hline Source : Central Burean of Statistics (BPS) Batam City 2014-2018
\end{tabular}

This research contributes to community perceptions after the presidential election and tries to find gaps that occur in the Batam city environment. focus

8 Power, Thomas P. 2018. "Jokowi's authoritarian turn and Indonesia's democratic decline." Bulletin of Indonesian Economic Studies 54 (3): 307-38. 
on the indicators of social welfare that have not been studied by researchers and practitioners. In the community perception, a lot is done about social welfare such as social security programs, social welfare services that are received directly by the community in an effort to anticipate and fulfill community needs in the event of economic risk ${ }^{9}$. However, this study is important that social welfare problems cannot be handled unilaterally and without clearly organized social conditions experienced by the community. Social change that dynamically causes the handling of these social problems must be well planned and sustainable. Because social problems will always exist and arise as long as the government is still running and human life is still there.

This study seeks to describe the perceptual values conveyed by the community towards the welfare they feel seen from various aspects of connectivity between regions, affordable logistics costs, inequality, improving the quality of life from year to year, local government welfare assistance, community participation, targeted government programs and empowerment of MSME as well as welfare from the education sector to job opportunities for the community of Batam city. Furthermore, this study aims to analyze community perceptions of social welfare conditions.

\section{Method of Research}

The research was conducted in July-August 2019. The research locations were spread in 12 selected sub-districts in Batam City, Riau Islands Province. The method used in this research is sure with descriptive method. Descriptive research by focusing on people's perceptions of social welfare in Batam City, Riau Islands Province. Furthermore, the research variables emphasize the criteria for community perceptions of social welfare in which the perception variables described by the community assessment in ten assessment criteria. Data were collected using a questionnaire that has been compiled by the researcher so that it is followed by population calculations. According to Sugiyono says that the definition of population is: "The area of generalization consisting of objects / subjects that have certain quantities and characteristics that are determined by researchers to be studied and then draw conclusions. While sample, is a part of the population that wanted to be studied or seen as a part of the population, but not the population itself ${ }^{10}$.

\footnotetext{
9 Wickenden, Elizabeth. 1960. "Social Security And Voluntary Social Welfare.” SAGE Publications, no 1. August.

10 Sugiyono. 2006. Statistik Untuk Penelitian. Alfabeta. Bandung. Page 6.
} 
The population of the total data that can be taken is $1,236,399$ people from 12 sub-districts scattered throughout Batam City. In this study, researchers took 123 people as samples, representing each district using purposive sampling. According to Arikunto said Purposive Sampling Technique is not based on random but based on considerations that focus on a specific goal so that it is carried out on binding considerations ${ }^{11}$.

Table 2. Population and Sample Community in Batam City

\begin{tabular}{llllll}
\hline \multirow{2}{*}{ No } & \multirow{2}{*}{ Sub-District } & \multicolumn{4}{l}{ Population of Batam City } \\
\cline { 3 - 6 } & & $\mathrm{M}$ & $\mathrm{F}$ & Population & Sample \\
\hline 1. & Belakang Padang & 9.673 & 9.556 & 19.229 & 2 \\
2. & Bulang & 5.246 & 4.678 & 9.924 & 1 \\
3. & Galang & 8.412 & 7.311 & 15.723 & 2 \\
4. & Sungai Beduk & 37.185 & 49.506 & 86.691 & 9 \\
5. & Sagulung & 43.048 & 43.145 & 86.193 & 9 \\
6. & Nongsa & 131.131 & 111.224 & 242.355 & 24 \\
7. & Batam Kota & 90.564 & 82.915 & 173.479 & 17 \\
8. & Sekupang & 33.362 & 29.771 & 63.133 & 6 \\
9. & Batu Aji & 33.983 & 31.352 & 65.335 & 7 \\
10 & Lubuk Baja & 121.954 & 121.998 & 243.952 & 24 \\
11 & Batu Ampar & 63.757 & 60.408 & 124.165 & 12 \\
12 & Bengkong & 53.023 & 53.197 & 106.220 & 10 \\
& Total & 631338 & 605061 & 1236399 & 123 \\
\hline
\end{tabular}

Source : Central Bureau of Statistics (BPS) the Riau Islands Province (2016)

For the data collection, used primary data and secondary data. Primary data obtained by means of interviews using questionnaires and observations. Secondary data were obtained from various writings and other data sources relevant to this research. Data analysis used a qualitative descriptive approach then processed using the Statistical Product and Service Solutions application and formulated as follows:

11 Arikunto, Suharsimi. 2006. Prosedur Penelitian : Suatu Pendekatan Praktik. Revisi VI.Jakarta: Rineka Cipta. 
Average Score

$$
X=\sum \frac{\text { (Questions Score x Frequency Score) }}{n}
$$

Scale Range

$$
R_{s}=\frac{(m-1)}{m}
$$

Information :

$\mathrm{n}:$ Total Sample

$\mathrm{m}$ : Total of alternative answers for each item

determine the scale range with the following formula :

$$
\begin{gathered}
S_{r}=\frac{(m-1)}{m} \\
S_{r}=\frac{(4-1)}{4}=0,6
\end{gathered}
$$

Table 3. Average Interpretations of Community Perceptions ${ }^{12}$

\begin{tabular}{ccc}
\hline No & Average & Interpretations \\
\hline 1 & $1,0-1,6$ & Strongly Disagree \\
2 & $1,6-2,2$ & Disagree \\
3 & $2,2-2,8$ & Agree \\
4 & $2,8-3,4$ & Strongly Agree \\
\hline
\end{tabular}

Source : Umar 2005

\section{Theoritical Framework}

Gibson in his book entitled The Perception of The Visual Word describes the factors that influence perception as follows:

12 Umar, Husein. 2005. Riset Sumber Daya Manusia Dalam Organisasi. Jakarta: Gramedia Pustaka Utama. 
a. Internal factors

(1) Physiological; Information enters through the senses, then the information obtained will influence and complement the effort to perceive each person differently so that interpretations of the environment can also be different

(2) Attention; Individuals need a certain amount of energy expended to pay attention or focus on the physical form and mental facilities that exist in an object. The energy of each person is different so that one's attention to objects is also different and this will affect the perception of an object.

(3) Interest; The perception of an object varies depending on how much energy or perceptual vigilance is moved to perceive. Perceptual vigilance is a person's tendency to pay attention to certain types of stimulus.

(4) Unidirectional Needs; This factor can be seen from how strong an individual is looking for objects or messages that can provide answers in accordance with theirself.

(5) Experience or Memory; Experience can be said to depend on memory in the sense of the extent to which a person can remember past events to know a stimulus in a broad sense.

(6) Emotional state; Emotional state affects a person behavior, this emotion shows how a person feels at a time which can affect how a person receives, reacts and remembers.

b. External factors

(1) Size and Placement of Stimulus; This factor states that the greater the relationship of an object, the easier it is to understand. This shape will affect individual perceptions and by looking at the size of an individual object it will be easy to pay attention to in turn shape perceptions.

(2) Color of Objects; Objects that affect light are more easily understood (to be perceived) than those that are less.

(3) Motion or Movement; Individuals will pay a lot of attention to objects that provide movement within the range of view compared to objects that are still.

(4) Intensity and Strength of Stimulus; The stimulus from the outside will give meaning to being noticed more often than what is seen only once. The power of the stimulus is the power of an object that can influence perception. 
(5) Stimulus Uniqueness and Contrast; An external stimulus whose appearance against the background and surroundings completely beyond the expectations of other individuals will attract a lot of attention ${ }^{13}$.

The process of the perception of a person's stimuli or reactions by type is divided into visual perception, auditory perception, tactile perception, olfactory perception, tasting perception and selective perception. Then in this case the researcher uses visual perception and selectively sees the research needs with the following explanation:

a. Visual Perception; is a general discussion that can be read by the eye both what we see before we see or imagine and after doing the object in question. This perception is the main topic as well as the one that is usually most discussed in everyday life

b. Selective Perception; that is, selectively interpret what someone sees based on the will, interest, general description of events, experiences and attitudes ${ }^{14}$.

The process of forming perceptions in individuals is influenced by various factors. . Robbins says that the factors that play a role in shaping a person perception can be on the perceiver side, in the object or target that is perceived, or in the context of the situation in which the perception is carried out ${ }^{15}$. In summary, the three factors are:

a. Situation Factors; Situations including time, work conditions or place, social circumstances can influence our perceptions. As stated by Walgito that the environment or situation in particular that is the background of the stimulus will also affect perception, especially if the object of perception is human. The object and the environment behind the object are roundness or unity that is difficult to separate. The same object in different situations can produce different perceptions ${ }^{16}$.

b. Preceiver factors; When an individual looks at an object and tries to interpret what they see, the interpretation is very much influenced by the personal characteristics of the preceiver. The factors attributed to the preceiver affect what they perceive.

13 Gibson, James J. 1950. The perception of the visual world. Methuen: The Riverside Press. Page 12.

14 Bjorklund, David F. 2000. Children's Thinking: Developmental Function and Individual Differences. Beverly: Wadsworth. Page 2.

15 Robbins, Stephen P. 2001. Organizational Behavior. South Africa: Prentice Hall. Page 89.

16 Walgito, Bimo. 2002. Pengantar Psikologi Umum. Daerah Istimewa Yogyakarta: CV Andi Offfset. Page 47. 
c. Factors at Target; The characteristics of the target to be observed can influence what is perceived. The target forms a way of looking at it according to, the characteristics intended are as follows:

(1) New thing; The characteristics of the target to be observed can influence what is perceived. The novelty, movement, sound, size and other attributes of the target shape the way we perceive it.

(2) Movement; This principle of movement states that people will pay more attention to moving objects within their range of view to objects those are still. From this movement of an object which attracts the attention a perception arises.

(3) Size; The larger the size of an object, the easier it is to be known or understood. The shape of the size will affect a person perception and by seeing the shape of the size of an object, people will be easily attracted to their attention which in turn can shape their perception ${ }^{17}$.

The aim of this research is to develop an operational definition of "perceptions" that occur in everyday life which is generally carried out by the community. (Walker and Avant 2005) stated that based on the structure and function of perception. There are eight main steps in identifying a perception, namely selecting a concept, determining the purpose of the analysis, identifying all possible uses of the concept, which consists of determining and defining attributes, identifying each existing model case, identifying additional cases (Injury Time), identifying antecedents and consequences. will happen, and the latter defines an empirical reference.

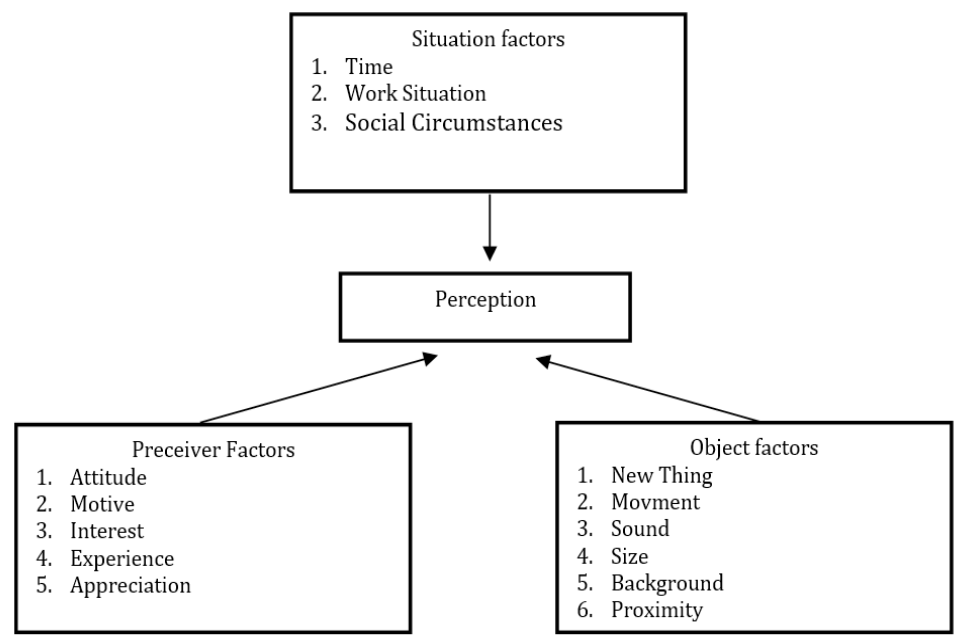

Source : (Robbins, Odendaal, and Roodt 2003)

17 Thoha, Miftah. 2002. Perilaku Organisasi. Jakarta: PT Raja Grafindo Persada. Page 126. 


\section{Findings and Review}

Batam, which is a vital area for absorbing the geographical conditions of the maritime border which is passed by the international shipping line and it is one of the dwelling areas for cargo ships from all over the world, is one of the main areas for stopover for imported goods without taxes.. This is actually indisputable if there is an assumption that Batam is a very attractive area for foreign investment. The phenomenon of the proliferation of international standard industries and the arrival of workers should be directly proportional to the welfare of the people in Batam City. However, in the past 5 years (Tri semester at the end of 2014 to 2019), Economic fluctuations also occur, as in the following:

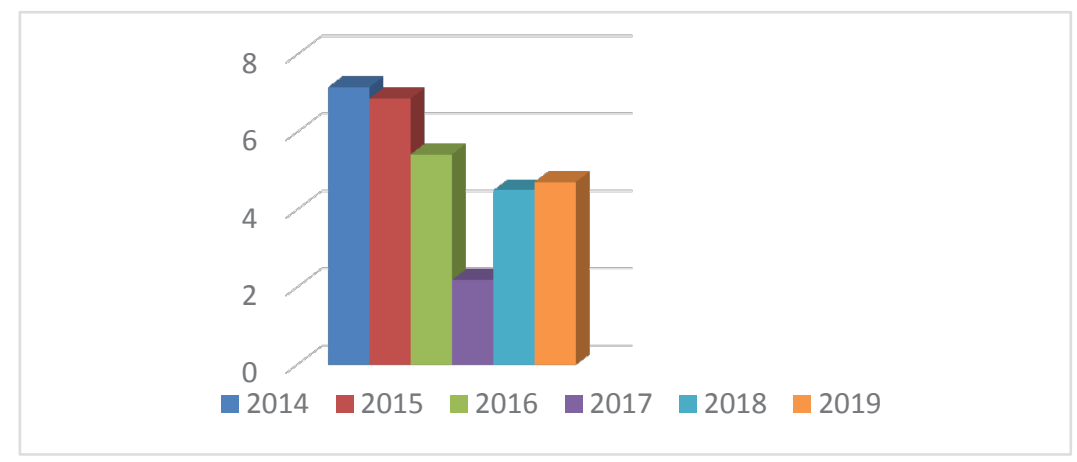

Source : Researchers own fieldwork. 2019

Even though in 2018 and 2019, the economy was crawling to experience recovery, in fact the condition of this city was not like or even better than in 2014, especially in 2017 which experienced a very bad number (2.19\%). The improvements in 2018 and 2019 were dominated by the tourism sector. The tourism sector is able to touch almost all lines of welfare indicators to improvise and make improvements in line with the demands of attracting tourists, while these indicators are; education, health, technology and information and assistance from the government. Community perceptions expressed in numbers cover all welfare indicators including access, education encouragement, government assistance and health. As for the political contestation that will occur and the dark situation in the past 5 years, not too much has affected community perceptions of the city of Batam.

Moreover, the high level of public trust in the incumbent to have positive implications for the growth of welfare in the city of Batam provides the 
implications that have been made such as management of the Batam Concession Agency (BP Batam) moving the Free Trade Zone (FTZ) to the Special Economic Zone (KEK) the community is expected to have positive impact on the welfare of society.

\section{Public Perceptions of Social Welfare in Batam City}

Social welfare is an organized system of social enterprises and institutions aimed at assisting individuals and groups to achieve satisfactory standards of life and health and to achieve individual and social relationships which enable them to develop their full abilities to enhance welfare. they are in tune with the needs of family and society ${ }^{18}$. Then Wilson stated that social welfare is a concern that is held from everybody for everybody ${ }^{19}$. Defines social welfare as a social enterprise that is organized and has the main objective of improving the community lives based on the social context. This includes policies and services related to various life in society such as income, social security, health, housing, education, recreation, cultural traditions and others. The explanation above implies that social welfare problems cannot be handled unilaterally and without clearly organized social conditions experienced by the community. Social change that dynamically causes the handling of these social problems must be well planned and sustainable. Because social problems will always exist and arise as long as the government is still running and human life is still there ${ }^{20}$.

There are 10 assessment criteria used to analyze the perceptions of community in Batam City on Social Welfare. These criteria are described below:

1. The achievement of inter-regional connectivity by the community (P1)

2. Logistics costs that are affordable to the community (P2)

3. Inequality / social disparities that occur among communities (P3)

4. Increased quality of community life from year to year (P4)

5. The availability of government assistance that is experienced by the community directly (P5)

6. Productivity / community participation in social welfare (P6)

7. Government programs for targeted social welfare experienced by the community (P7)

8. Empowerment of local wisdom / MSME that is right on target experienced by the community (P8)

18 Fridlander, Walter A. 1968. Introduction to Social Welfare. 3rd ed. New York: Prentice-Hall.

19 Wilson, Gertrude. 1949. Social Group Work Practice. England: Houghton Mifflin.

20 Wickenden, Elizabeth. 1960. "Social Security And Voluntary Social Welfare." SAGE Publications, no 1. August. 
9. Vacancies for difficult jobs or high levels of unemployment experienced by the community (P9)

10. Social economic welfare in education experienced by the community (P10)

The ten criteria that have been described above are then scored based on the assessment of the Batam City community then identify the position of the decision, an assessment of public perceptions and the judgment decision is based on the average score. Based on the indicators in making a decision and compared with the average score of each perception statement, the results obtained in the city of Batam can be described for each district can be seen in the following table:

Tabel 2. Respondents Perception Assessment Criteria by Sub-Districts Against Social Welfare in Batam City in 2019

\begin{tabular}{ccccccccccc}
\hline \multirow{2}{*}{ Sub-Districts } & \multicolumn{1}{c}{ Assessment criteria } \\
\cline { 2 - 10 } & P1 & P2 & P3 & P4 & P5 & P6 & P7 & P8 & P9 & P10 \\
\hline Belakang & 2.50 & 2.50 & 3.0 & 3.0 & 3.0 & 3.0 & 3.0 & 3.0 & 3.50 & 3.50 \\
Padang & & & & & & & & & & \\
Bulang & 2.0 & 3.0 & 2.0 & 3.0 & 3.0 & 3.0 & 3.0 & 4.0 & 4.0 & 3.0 \\
Galang & 2.50 & 1.50 & 2.50 & 1.50 & 2.0 & 2.50 & 2.50 & 2.50 & 3.50 & 2.0 \\
Sungai Beduk & 2.56 & 3.22 & 2.67 & 2.56 & 2.78 & 3.22 & 2.44 & 2.33 & 3.11 & 3.0 \\
Sagulung & 3.11 & 3.33 & 2.67 & 3.0 & 3.22 & 2.89 & 2.89 & 3.0 & 3.11 & 3.11 \\
Nongsa & 3.04 & 3.04 & 2.75 & 2.92 & 3.08 & 2.96 & 2.83 & 2.50 & 3.08 & 3.04 \\
Batam Kota & 2.82 & 2.65 & 2.71 & 2.41 & 2.35 & 3.0 & 2.82 & 2.76 & 3.47 & 3.06 \\
Sekupang & 2.17 & 2.67 & 2.83 & 2.67 & 2.67 & 2.67 & 2.50 & 2.50 & 2.67 & 2.50 \\
Batu Aji & 2.71 & 2.43 & 2.71 & 2.43 & 2.43 & 3.0 & 2.29 & 2.29 & 3.14 & 2.29 \\
Lubuk Baja & 3.0 & 3.0 & 2.54 & 3.0 & 3.04 & 2.96 & 2.83 & 2.71 & 3.08 & 3.04 \\
Batu Ampar & 2.75 & 2.67 & 3.50 & 3.17 & 2.92 & 2.75 & 2.92 & 2.33 & 3.67 & 2.91 \\
Bengkong & 2.70 & 2.40 & 3.0 & 2.80 & 2.70 & 2.80 & 2.70 & 2.70 & 3.50 & 2.50 \\
\hline
\end{tabular}

Source: processed data by SPSS 16.0

Based on the results of the analysis of community perceptions of social welfare in each sub-district which has been described in the table above, the overall results of public perceptions in Batam City can be seen in the following table: 
Table 2. Public Perception Assessment Decisions in Batam City in 2019

\begin{tabular}{llll}
\hline No & Assessment Criteria & $\begin{array}{l}\text { Average } \\
\text { Value }\end{array}$ & Decicsion \\
\hline P1 & $\begin{array}{l}\text { The achievement of inter-regional connectivity } \\
\text { by the community }\end{array}$ & 2.8 & $\begin{array}{l}\text { Strongly } \\
\text { Agree }\end{array}$ \\
P2 & $\begin{array}{l}\text { Logistics costs that are affordable to the } \\
\text { community }\end{array}$ & 2.8 & $\begin{array}{l}\text { Strongly } \\
\text { Agree }\end{array}$ \\
P3 & $\begin{array}{l}\text { Inequality / social disparities that occur } \\
\text { between communities }\end{array}$ & 2.8 & $\begin{array}{l}\text { Strongly } \\
\text { Pgree }\end{array}$ \\
P4 & $\begin{array}{l}\text { Increased quality of community life from year } \\
\text { to year }\end{array}$ & 2.8 & $\begin{array}{l}\text { Strongly } \\
\text { Agree }\end{array}$ \\
P5 & $\begin{array}{l}\text { The availability of government assistance that is } \\
\text { experienced by the community directly }\end{array}$ & 2.8 & $\begin{array}{l}\text { Strongly } \\
\text { Agree }\end{array}$ \\
P6 & $\begin{array}{l}\text { Productivity / community participation in social } \\
\text { welfare }\end{array}$ & 2.9 & $\begin{array}{l}\text { Strongly } \\
\text { Agree }\end{array}$ \\
P7 & $\begin{array}{l}\text { Government programs for targeted social } \\
\text { welfare experienced by the community }\end{array}$ & 2.7 & Agree \\
P8 & $\begin{array}{l}\text { Empowerment of local wisdom / umkm that is } \\
\text { right on target experienced by the community }\end{array}$ & 2.6 & Agree \\
P9 & $\begin{array}{l}\text { Vacancies for difficult jobs or high levels of } \\
\text { unemployment experienced by the community }\end{array}$ & 3.2 & $\begin{array}{l}\text { Strongly } \\
\text { Agree } \\
\text { P10 }\end{array}$ \\
$\begin{array}{l}\text { Social economic welfare in education } \\
\text { experienced by the community }\end{array}$ & 2.9 & $\begin{array}{l}\text { Strongly } \\
\text { Agree }\end{array}$ \\
\hline
\end{tabular}

Source: processed data by SPSS 16.0

\section{Conclusions and Recommendations}

Based on the results of the research, it is proven by data analysis that has been carried out and has been discussed, the researchers can conclude the following conclusions, including:

1. The people of Batam city strongly agree that; 1) Inter-regional connectivity is achieved by the community, 2) Logistics costs are affordable by the community, 3) Social imbalances / disparities that occur between communities, 4) Increasing community life quality from year to year, 5) Availability of government assistance that is experienced by the community Directly, 6) Productivity / community 
participation in social welfare, 7) Difficult job vacancies or high levels of unemployment experienced by the community and 8) Social economic welfare in education experienced by the community.

2. The perception of the people of Batam city only agrees that 1) Government programs on targeted social welfare are experienced by the community, 2) Empowerment of local wisdom / MSMEs those are right on target experienced by the community.

3. The accessibility of the community is very supportive of welfare in Batam City, and the community tend not to be skeptical of policy products taken by the government to improve the welfare of the people in Batam.

4. Contestation in the presidential election and the context of issues of conservatism, repressive leadership, and populism in Indonesia do not have a significant negative impact on community perceptions in terms of community welfare.

\section{Recommenfations}

1. The community of Batam City must be given by the local government to further develop and seek strategic policies to implement targeted social welfare programs that can be experienced directly by the community of Batam City.

2. The people of Batam City must be given education about empowering local wisdom / MSMEs that are right on target, especially sub-districts which are considered to have the potential to develop local wisdom in order to achieve equitable social welfare.

3. The community needs to be involved together with the government in an effort to improve community welfare through private sector cooperation / Collaborative Governance so that a better sustainable economy can be strengthened.

4. The positive achievements by the government in treating the economic downturn in this quite prima donna region require more improvisation, especially in the form of policy flexibility. This improvement, which is fully supported by the tourism sector, requires measured and mature value added. 


\section{Reference}

Arikunto, Suharsimi. Prosedur Penelitian : Suatu Pendekatan Praktik. Revisi VI. Jakarta: Rineka Cipta, 2006.

Bjorklund, David F. Children's Thinking: Developmental Function and Individual Differences. Beverly: Wadsworth, 2000.

Fridlander, Walter A. Introduction to Social Welfare. 3rd ed. New York: PrenticeHall, 1968.

Gibson, James J. The perception of the visual world. Methuen: The Riverside Press, 1950.

Gregory, Richard L. Perceptions. Psychology. New York: Routledge, 1987.

Kelley, Harold H. Attribution in Social Interaction. Morristwon: General Learning Press, 1971.

Kinicki, Angelo., and Robert. Kreitner. Organizational Behavior: Concepts, Skills \& Best Practices. Fourth, 2005.

Kotler, Philip. Marketing Management. Prentice Hall of India, 2000.

McDonald, Susan M. "Perception : A concept analysis."Internasional Journal Of Nursing Knowledge 23, 1 (2012): 1-8.

Power, Thomas P. “Jokowi's authoritarian turn and Indonesia's democratic decline." Bulletin of Indonesian Economic Studies 543 (2018): 307-38.

Robbins, Stephen P. Organizational Behavior. South Africa: Prentice Hall, 2001. Robbins, Stephen P., Aletta. Odendaal, and G. Roodt. Organizational Behavior : Global and Southern African Perspectives. Pearson Education South Africa, 2003.

Schacter, and Daniel. Psychology + Psychinvestigator. New York: Worth Publisher, 2011.

Sugiyono. Statistik Untuk Penelitian. Alfabeta. Bandung, 2006.

Thoha, Miftah. Perilaku Organisasi. Jakarta: PT Raja Grafindo Persada, 2002.

Umar,Husein. Riset Sumber Daya Manusia Dalam Organisasi.Jakarta: Gramedia Pustaka Utama, 2005.

Walgito, Bimo. Pengantar Psikologi Umum. Daerah Istimewa Yogyakarta: Andi Offfset, 2002.

Walker, Lorraine Olszewski, and Kay Coalson Avant. Strategies for Theory Construction in Nursing. Edited by 4th. Sixth. New York: pearson, 2005. 
Wickenden, Elizabeth. "Social Security And Voluntary Social Welfare." SAGE Publications, 1960.

Wilson, Gertrude. Social Group Work Practice. England: Houghton Mifflin, 1949. 